\title{
Usage of Digital Educational Resources in Teaching Students with Application of "Flipped Classroom" Technology
}

\author{
Albina R. Drozdikova-Zaripova \\ Kazan (Volga region) Federal University, Russia \\ ORCID: 0000-0003-0354-8090 \\ Elvira G. Sabirova \\ Kazan (Volga region) Federal University, Russia \\ ORCID: 0000-0002-1546-9237
}

Received: 6 May 2020

Accepted: 15 Aug 2020

\begin{abstract}
Modern educational process has to take into account the tendencies in science and tech advancement and also demands of society to quality of education services. As one of the most effective ways, there is reasonably considered purposeful usage of digital educational resources. In this study, there has been considered modern educational technology of "Blended learning" by model of the "Flipped classroom", that is based on the concept of unifying the technology of "class-lesson system" and technology of digital teaching on the grounds of new didactic possibilities given by ICT (informational and communicational technologies) and modern teaching means. Theoretical methods among which there are analyzing, comparing and summarizing the research subject on the base of psychological and pedagogical literature; query-diagnostic method that help to evaluate effectiveness of digital educational resources usage in teaching students with application of "Flipped classroom" technology. In the carried study, there are shown different variants and technological means in realization of "Flipped classroom" when making digital educational resources on subjects of "Methodology and methods in organizing scientific research" and "Method of teaching mathematics". According to survey results it can be stated that students sufficiently highly evaluate the level in organization of teaching, the content of digital educational resources and also qualification and responsiveness of teachers. Study results can be used at development of teaching courses, digital educational resources that are introduced within scope of higher education, when making comparative studies for working out design methodology for digital educational resources. Pilot project on introduction of new educational technology on within realization scope of digital education resources at various levels of higher professional education, was held on the base of Kazan (Volga region) federal university institute and proved its trustworthiness.
\end{abstract}

Keywords: flipped classroom technology, blended learning, digital educational resource, informational and educational environment of higher education institution

\section{INTRODUCTION}

Competent entry into digital age conditions demands of society to new types of work, to increasing efficiency of professional activity and to training quality of specialists who assuredly are needed on job marked, who easily and freely master mobile and internet technologies, and also has intent on continual training with usage of digital education technologies (Cortez, 2020; Kondratenko, 2015; Larionova et al., 2018; Mendoza \& Mendoza, 2018; Min \& Nasir, 2020; Roschelle et al., 1998; Ryu \& Parsons, 2009; Salas-Rueda et al., 2020; Spikol, Kurti, \& Milrad, 2008; Toto, 2019; Zyubina et al., 2019). 
Analysis of educational practice in the last decades shows that present translational and educational technologies of higher education are often criticized because of delivering knowledge in finished form, passivity of students in education process and impossibility in full measure to develop basic competitions on studied subjects (Firsova et al., 2018; Kasprzak \& Kalashnikov, 2014; Margolis, 2014; Razumovskaya et al., 2018, 2019).

In modern education special attention is paid to development of personal qualities in students, their common culture, understanding the value of education, inner motivation and responsibility for their own training.

Another important problem that needs solving is arrangement of self-dependent work of students especially strongly this problem appears in distance education where one of the main tasks is the implementation of students' self-dependent work, and the amount of hours spent on it greatly exceeds the number of classroom hours.

In connection to this, during the last years there appeared need of serious change in education process technology going on in higher education institutions.

Modern educational process has to stand on new development tendencies in science and tech. The most perspective trend in development of modern higher education is wider usage of various possibilities in digital training and step by step movement from traditional methods and technologies of teaching to "Blended learning" with choice of more effective "Flipped classroom" model.

Choice of this technology agrees with the view point of New Media Consortium that is the international association of experts in educational technologies and it concurs with ideas of informational technology developers' association that works for higher education within scope of educational project Educause (Eli). This choice is the crucial trend that does considerable influence on higher education system around the world (Report NMC Horizon, 2015).

Introduction of digital technologies into teaching creates new possibilities in working out arrangement and content of educational process, in designing individual education routes, in changing focus of students from position of digital source consumer to position of active creativity. However, digital education environment demands from pedagogues another mentality, other perception of the world, entirely different approaches and forms of work with students.

Thus, studying the experience of bringing in digital education resources in teaching students with usage of "Flipped classroom" technology, besides its actuality, it represents great practical significance.

\section{LITERATURE REVIEW}

Conducted historical excursion shows that notion "Flipped classroom" became extensively used since mid of 2000s, when it was popularized by chemistry teachers Bergmann and Sams (2012). Nevertheless, the concept of "Flipped classroom" appeared somewhat earlier.

At the beginning 90 s of the $20^{\text {th }}$ century, professor of Harvard University Eric Mazur did the first experiments on usage of "flipped teaching" technology. He printed his lectures and gave those papers to students who were told to read the learning material the day before. Students came to lessons and professor offered them to answer several questions and tests. During the lessons on studied theme there went discussions between students and together the solved complex problems (Crouch \& Mazur, 2001). His own method Eric Mazur called Peer instruction.

Later this model was extended and consequent studies were intended on development of technological aspects. In the year 2000, in his work, Baker (2000) accentuated about significance of system role in online teaching management, and also about teacher's role as the facilitator and trainer (Baker, 2000).

Following studies were focused on "class inversion" notion as the mean of providing inclusive teaching environment based on personalized coaching and tutoring (Lage, Plat, \& Treglia, 2000). 
Further, the model of "blended learning" got development in the middle of 2000s at schools and universities of USA (Bergmann \& Sams, 2012).

Nowadays, the most successful practice of "flipped" teaching programs takes place in University of Pennsylvania (USA) and University of Vanderbilt (USA). The concept widely spread in United Kingdom (University of Manchester), in Australia (University of Queensland), and also in many universities of our country.

Foundation of modern education in "blended learning" is constituted by the unity concept of auditorium teaching technology under immediate management of teacher and digital education technology that are based on new didactic possibilities given by informational and communicational technologies (ICT), and modern teaching means (Butakova et al., 2020; Luchenkova, Noskov, \& Shershneva, 2015; Mohova, 2005).

In recent years, there appeared thematic studies where are proved the facts about motivation increase of students and teachers, about more attendance in classes, about improving academic performance due to flipped approach (Sharples et al, 2014; Yarbro et al., 2013).

It is proved that usage of blended teaching in higher education environment provides motivation increase in cognitive activity, development of skills in self-dependent work, also it forms awareness, self-discipline, and elaborates creative potentiality of students (Sun, Liu, \& Luo, 2017).

Advantage of "Flipped classroom" technology is that it stimulates activity of students in learning process by rational usage of curricular and extracurricular time; personalization (self-government) of pedagogical process (Downes, 2016; Vasilyeva, Rodionova, \& Chicherina, 2019).

Modern researches show content characteristics and effectiveness of "Flipped classroom" usage with regard to specifics of educational courses and various educative internet platforms (Kim et al., 2014; Pavelyeva, 2017; Vorobyev \& Murzaeva, 2018; Zainuddin \& Halil, 2016).

In context of higher education, teachers develop qualitatively various concepts of "Blended learning", and also develop approaches to teaching and designing of academic courses (Bluic et al., 2012). There are many described models of this technology realization (Kaygorodova \& Shkurko, 2016; Peres, Lima, \& Lima, 2016).

In higher education practice there are possible such options as total reconstruction of education process, and so are the partial ones, for instance, the usage of only some elements of flipped model or applying this model at several lessons during the semester.

\section{MATERIALS AND METHODS}

\section{Purpose of the Research}

Purpose of this study is to analyze experience in realization of digital education resources when teaching students with usage of "Flipped classroom" technology.

\section{Methods and Methodic of Study}

For study realization there were chosen complex of inter-complementary methods: 1) theoretical (theoretical analysis of psychological and pedagogical literature, comparing and summarizing the experience); empirical (pedagogical experiment, query-diagnostic method, observing); methods of processing data (quantitative and qualitative analysis).

In this study there were applied the following methodic:

1) Methodic for diagnostic of students' learning motivation (Rean, Yakunin, modification of Badmaeva, 2004);

2) Questionnaire "Diagnostic of self-organizing particularities-39" (DSP-3) (Ishkov, 2004). 
3) Survey of feedback connection to evaluate effectiveness in teaching arrangement, content of digital education resources (DER), and also qualification of teacher. For pedagogical analysis there were selected some monitoring indexes of students' opinions that were formed in type of statements with ordinal scale of marks: $1,2,3,4,5,6,7$, where " 1 " means completely unsatisfactory, "7"-totally satisfactory. All the indexes of survey are grouped into three rubrics of quality with several indexes in every part.

\section{Experimental Base of Study}

Experimental work was done on the base of Kazan (Volga region) federal university institute of psychology and education. In this study there participated 30 undergraduate-external students of the $1^{\text {st }}$ year specializing in direction 44.04.02. of psychological and pedagogical education ( 3 learning groups in three training profiles: "Psychology and social pedagogics"; "Psychology and pedagogics of children and youth sports"; "Psychology and pedagogics of inclusive education"). These students have course in discipline of "Methodology and methods of organizing scientific study". Also there participated 35 full-time baccalaureate students of the $4^{\text {th }}$ year who specialize in "Elementary education" and have course in "Method of teaching mathematics" discipline.

\section{Stages of Experiment}

The study was done conventional conditions, in three stages:

1. At the searching-theoretical stage there was done analysis of pedagogical and psychological literature about study theme, there was defined scientific apparatus and research base, made plan of experimental study.

2. At the experimental stage there was done introduction of present digital education resources with application of two technological realization ways of "Flipped classroom" when learning by the $1^{\text {st }}$ year undergraduate-external students the discipline of "Methodology and method of organizing scientific study" and when learning by the $4^{\text {th }}$ year baccalaureate students the discipline of "Method of teaching mathematics". With the purpose to confirm effectiveness of applied "Flipped classroom" models there was done psychological-diagnostic procedure at the stage of start and finish in learning disciplines in different purpose groups (undergraduate externals and baccalaureates) in accordance with given criteria: motivation of education activity and self-organizing of students. As the feedback connection after ending of online courses with auditorium built-in interactive components, there was carried out survey with the help of Google-form, intended to get information about self-evaluation effectiveness in teaching arrangement, content of DER, and also about qualification of teachers.

3. At the summarizing stage there was done systematization and processing of study results, formed theoretical and experimental conclusions. Evaluation of reliable differences and shifts in experimental data was done using t-criterion of Student for linked and not linked selections.

\section{RESULTS AND DISCUSSION}

\section{"Blended Learning" Educational Technology Based on "Flipped Classroom" Model within Realization Scope of Digital Education Resource in Accord to "Methodology and Methods of Organizing Scientific Study" Discipline}

According to curriculum plan, the "Methodology and methods of organizing scientific study" discipline is included into the block of basic part and it is optimized course for distant learning students who specializes in psychological and pedagogical education by three programs of undergraduate training.

The discipline is delivered at the $1^{\text {st }}$ year during the $1^{\text {st }}$ semester, on this course for self-dependent work there is given 83 hours and 16 auditorium hours.

As a result of acquiring the "Methodology and methods of organizing scientific study" discipline students should have formed general professional competitions. 
As the platform for realization DER there was chosen "Virtual auditorium" module that is included into structure of informational and analytical system called "Electronic university" functioning in Kazan (Volga region) federal university. This module is intended for conducting distant education and checking knowledge of students.

Structure of "Methodology and methods of organizing scientific study" discipline consists of three sections. Every section of the course includes methodic recommendations about learning the section, teaching material (video-lectures, presentations, theoretical material), questions for consideration and additional resources on the section, supplementary tasks, test control, evaluation means.

Here is more detailed information about methodic of entering DER into educational process with usage of "Flipped classroom" technologies.

There was chosen scenario of "Flipped classroom" with partial saving of auditorium lecture lessons with aim to adapt first year students to new format of education process.

Among crucial purposes of using this technology there were ascertained the following:

- optimization of learning process, above all, on account of theoretical material and carrying out the part of interactive work in extracurricular way;

- improving effectiveness of self-dependent work by students (achieved owing to accurately organized current control, creating interactive education environment);

- increasing motivation level of students;

- forming in students sense of responsibility for their own education;

- transformation of students into active participants of education process.

The essence of "Flipped classroom" technology is in its cardinal rearrangement of main stages in learning process.

Learning process within such kind of teaching model represents by itself phasic sequence of traditional and distant or digital education, which alternate periodically.

"Flipped classroom" model includes designing, organizing and carrying out teaching process where are supposed initial extracurricular acquaintance of students with new learning material through work with online resources presented by teacher (more often there are used video lectures). Self-dependent learning educational material is done at any convenient time, in individual tempo without time limitations. Auditorium work is dedicated to extending and fixing in memory information got through discussion of more important and complex issues, and also to doing practical tasks immediately by guidance of teacher and interaction by classmates. Further fixation and self-dependent work with learning material goes in extracurricular way.

Used educational technology cardinally changes students' and teachers' activity.

Functionality of teacher broadens and changes as at the stages of preparing and performing educational process so at organizing of extracurricular communication on the base of chosen educative internet platform (Figure 1).

Acquiring of the course starts since acquaintance with interface of "Virtual auditorium" and since the stage of involving students into teaching process with help of introductory video-lecture, where the new education concept is explained to students, also students become the members of closed group in social network Vkontakte "MetoDOM Nauki".

Making group in Vkontakte is conditioned by need of getting operative information and additional materials, organizing active discussion on studied questions with classmates and teacher, exchanging experience, making evaluation of students' works, participating in surveys. 


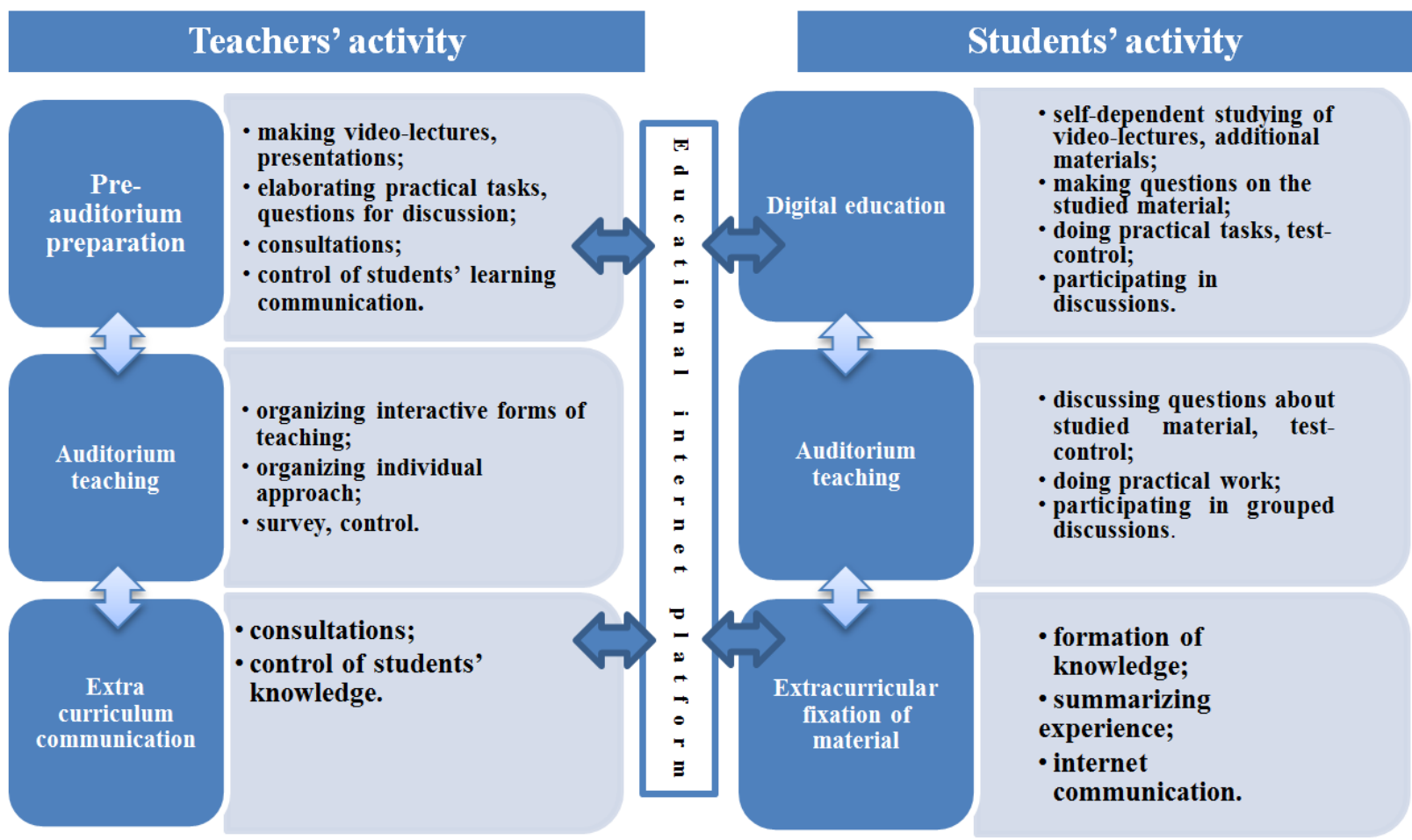

Figure 1. Methodic aspects of "Blended learning" technology on the model of "Flipped classroom"

Students studying every section of the course, initially in self-dependent way study, at any convenient time and place, announced theme on offered video-lections, presentational materials, references on additional materials posted in "Virtual auditorium".

Preparing and making record of video-lectures was done with the help of software "JALINGVA STUDIO" (technical possibilities of the software help to create and edit presentations, easily and operatively without assistance to make record and broadcast video). When creating presentations in this software, it is possible to do various work with objects (to relocate, hide and show), to add objects (file, text, browser, graphs), to change position of lector, to write on glass board during record.

Duration of video fragments was about 7-12 minutes, every video went with clear educative purposes and with gradual instruction when it was needed.

At preparing video-lectures, there were applied various ways of leading cognitive activity of students. For example, there were used diverse mnemonics: associations, schemes etc., for drawing and keeping attention there were practiced dynamic, emotionally enriched speech.

Further, on the learnt material students make questions, on the content of video-lectures they make short conspectus, fulfill offered interactive practical tasks which are later checked at practical lessons or included into list of self-dependent practical work, and also participate in online discussions by means of education internet platform forums (Virtual auditorium) and have discussions in social networks, in Vkontakte.

For arrangement to review education material mastered by students there are possible the following variants: 1) carrying out online-survey or teaching tests in various formats, for example online with digital service usage or at the start of practical lesson with usage of interactive test. Timely reaction of students on this surveys and possibility to watch lectures again help to clear diverse not understood moments in mastering studied material; 2 ) other variant of control in mastering given material is linked with quality estimation of fulfilling offered in video-lectures practical tasks.

At practical auditorium lessons students participate in grouped discussions on crucial aspects of theoretical material and on results of fulfilled practical tasks, also take part in grouped work on fulfilled problematic 
tasks, in discussing definite situations, in role games, elaborating elements of research projects etc. In this process every student can freely state one's own view point in searching optimal solution of tasks.

At practical lessons there were widely practiced grouped forms of work. Group structure depends on tasks given at lesson, there are possible the following variants: groups are formed with regard to program of undergraduate students training and to them, there are offered thematic projects, then there is used, for instance carousel method and there goes interchange with work samples of other groups' participants, at this point every group has to give as critical evaluation so to find advantages of the worked out project.

In another variant group structure is chosen at random and group participants fulfill same problematic tasks, which results are evaluated on competitive base.

Further fixation of material in memory is done by students again in a way of digital learning (for example, doing test, fulfilling self-dependent semester work participating in discussion, learning additional material, mutual evaluation, etc.).

Procedure of mutual evaluation can be arranged in the following way: initially students make post of selfdependently done task in a group at Vkontakte social network, and then other students in their commentaries to the income message evaluate those tasks applying criteria given by teacher. The number of unknown works that are offered to each student for evaluation have to be strictly limited. By the end, every student gets marks for one's own work and for evaluating the works of one's classmates.

Every learnt section is concluded by doing teaching test, which students can do at any time, the number of attempts is not limited, the level of satisfactory evaluation is $55 \%$.

Summary testing on the course is done in a form of control testing, it is carried out in ascertained by teacher time, with control of time and showing the level of satisfactory mark - $70 \%$. The correct answers of summary test are not available for students.

Procedure of testing goes in online routine using resource elements of teaching management system (Virtual auditorium).

Intermediate attestation (exam) on the course is done in traditional form and its results will be influenced by activity results of students at practical lessons, quality of done self-dependent work, participation activity at internet discussions and also by results of summary testing.

\section{"Blended Learning" Education Technology based on the "Flipped Classroom" Model within Realization Scope of Digital Education Resource in Accord to "Method of teaching Mathematics" Discipline}

"Method of teaching mathematics" discipline is given during one year for full-time students of the $4^{\text {th }}$ course that specialize in "Elementary education and foreign (English) language. It consists of two big sections, each is studied by students during semester, the first section belongs to general methodic and its content practically is not changed. The second methodic belongs to specific methodic and very much depends on content of subject field in "Mathematics and informatics" school course. Digital education resources are made to support the second section of discipline, it has vodcast, podcast and pre-vodcasting. Vodcast (videoon-demand) is a video file. In the course there are used resources of such platforms as Khan Academy (Arithmetic and basics of algebra, Theory of probability and combinatory, Development mathematics, Arithmetic. Podcast is an audio filed lecture, students can download podcasts to their own mobile and stationary devices or listen to lectures online. Some webinars were converted into audio files. Students listened to audio materials very actively. Pre-vodcasting: there were done 6 video records on pre-vodcasting method. Videos were watched by students before studying new section. Video-lectures were intended on actualizing students' knowledge, on setting the study purposes of given theme. Students fulfilled simple cognitive actions self-dependently (getting knowledge and remembering), and accentuated their attention on more complex forms of cognitive activity (comparing, analysis, synthesis, evaluation, application) in auditorium together with other students and teacher. 
Table 1. Division in learning activity motives of students in groups of baccalaureates and undergraduates, before and after realization of digital education resources

\begin{tabular}{|c|c|c|c|c|}
\hline \multirow[b]{2}{*}{ Motives of learning activity } & \multicolumn{2}{|c|}{ Baccalaureates } & \multicolumn{2}{|c|}{ Undergraduates } \\
\hline & Before & After & Before & After \\
\hline communicative motives & $3.68^{* *}$ & $4.47^{* *}$ & $3.8^{* *}$ & $4.45^{* *}$ \\
\hline avoiding motives & 2.79 & 2.86 & 3.15 & 2.98 \\
\hline prestige motives & 3.34 & 3.52 & 3.44 & 3.73 \\
\hline professional motives & $3.63^{* *}$ & $4.34^{* *}$ & $3.22^{* *}$ & $4.12^{* *}$ \\
\hline creative self-realization motives & 3.23 & 3.53 & 3.54 & 3.92 \\
\hline educative-cognitive motive & $3.53^{* *}$ & $4.43^{* *}$ & $3.64^{* *}$ & $4.42^{* *}$ \\
\hline social motives & 3.2 & 3.5 & 3.43 & 3.63 \\
\hline
\end{tabular}

note: ${ }^{* *}$ - differences at $\mathrm{p}<0.01$

Methodic of building-in online course of discipline into educational process is in distinct division of course material into students' homework that includes watching video-lectures; listening to audio-lectures, reading texts, discussing questions in chats, and also into auditorium interactive work of students that included discussions, brainstorms, business games, role games making of intellect charts, discourse tree, applying methodic of "6 hats of reasoning", and "Aquarium".

Particularity of arranging course content in accord to technology was in the work that was carried out depending on results of learning but not depending on content. Special attention was paid to feedback connection, its auditorium and digital constituent. Additional digital resources used in work were directed to broadening of notions, to development of professional skills and abilities of students.

\section{Effectiveness Evaluation of "Flipped Classroom" Model within Realization Scope digital Education Resources in Accord to "Methodology and Methods of Organizing Scientific Study" and "Method of Teaching Mathematics" Disciplines}

On the diagnostic results base of students' learning motivations, there are revealed hierarchy of motives in students' learning activity in baccalaureates and in undergraduates at the stages of starting and finishing digital education resources realization in accord to "Method of teaching mathematics" and "Methodology and methods of organizing scientific study" disciplines.

On the base of results comparative analysis, at the introducing stage of digital education resources, there can be stated that the set of motives in learning activity of baccalaureate and undergraduate students are alike. As the more significant motives baccalaureate and undergraduate students relate communicative and educative-cognitive motives. In hierarchy of dominating in significance motives baccalaureates accentuate also professional motives and undergraduates accentuate motives of creative self-realization. The least significance in two groups is given to avoiding motive.

At the finish stage of acquainting with digital educational resources there are revealed changes in structure of students' motivation set, there is increased significance level of studied motives (increased maximal scores reflecting significance of motives), with exclusion of undergraduates' avoiding motives.

In two selections, statistically reliable shifts are found in such indexes as communicative, professional and educative-cognitive motives.

Group figures of self-organizing components at the start and finish stage of digital education resources realization in baccalaureate and undergraduate students are presented in Table $\mathbf{2}$.

Comparative analysis on self-organizing components at the initial stage of studying the courses with usage of DER on the "Flipped classroom" model showed that functional components of self-organizing and personal component ("Will efforts") of baccalaureate and undergraduate students corresponds to average level, and this point as the dominating component of self-organizing is "Purpose setting" and the least developed one is "Correction". It is important to notice that the figures of diagnosed self-organizing components and figures of general level are higher in undergraduates than in baccalaureates, with the exclusion of "Will efforts" 
Table 2. Division in self-organizing components of baccalaureate and undergraduate students, before and after realization of digital education resources

\begin{tabular}{lcccc}
\hline & \multicolumn{2}{c}{ Baccalaureates } & \multicolumn{2}{c}{ Undergraduate } \\
\hline Self-organizing components & Before & After & Before & After \\
\hline purpose setting & 64.2 & 65.8 & $68.5^{* *}$ & $72.5^{* *}$ \\
analysis of situation & $62.1^{* *}$ & $70.6^{* *}$ & $63.3^{* *}$ & $71.2^{* *}$ \\
planning & $54.2^{* *}$ & $58.4^{* *}$ & $60.3^{* *}$ & $65.4^{* *}$ \\
self-control & 60.4 & 62.3 & $61.3^{* *}$ & $67.4^{* *}$ \\
correction & 51.2 & 53.1 & 54.8 & 56.2 \\
will effort & $60.4^{* *}$ & $63.4^{* *}$ & 58.6 & 60.2 \\
general level of self-organizing & $58.7^{* *}$ & $62.3^{* *}$ & $60.8^{* *}$ & $65.5^{* *}$ \\
\hline
\end{tabular}

note: ${ }^{* *}$ - differences at $p<0.01$

Table 3. Teaching quality self-evaluation done on "Flipped classroom" model in baccalaureate and undergraduate students

\begin{tabular}{lcc}
\hline Rubrics / indexes & Baccalaureates & Undergraduates \\
\hline Rubric 1. Teaching arrangement level & & \\
\hline Elaboration of course program & $6.42 \pm 0.43$ & $6.37 \pm 0.58$ \\
Quality of material delivering & $6.17 \pm 0.68$ & $6.23 \pm 0.59$ \\
Educational value of content & $6.45 \pm 0.44$ & $6.34 \pm 0.48$ \\
Convenience of forum organizing & $5.76^{* *} \pm 1.2$ & $6.45^{* *} \pm 0.45$ \\
Evenness of learning graphic & $6.34^{*} \pm 0.48$ & $5.89^{*} \pm 1.1$ \\
\hline Rubric 2. Qualification and responsiveness of teacher & & \\
\hline Teacher successfully delivered lectures/presentations & $6.43 \pm 0.39$ & $6.4 \pm 0.36$ \\
Video lectures and presentations were understandable and well organized & $6.56 \pm 0.38$ & $6.6 \pm 0.35$ \\
Teacher effectively used time of the course & $6.23 \pm 0.48$ & $6.12 \pm 0.35$ \\
It was possible to address the teacher and to get help & $6.78 \pm 0.28$ & $6.86 \pm 0.18$ \\
Evaluation marks were given quickly and with informative response & $6.1 \pm 0.98$ & $5.79 \pm 1.02$ \\
\hline Rubric 3. Content of digital education resource & & \\
\hline Purposes of teaching were clear & $6.59 \pm 0.37$ \\
Course was well organized and planned & $6.45 \pm 0.25$ & $6.67 \pm 0.39$ \\
Teaching load on the students was justifiable & $6.23^{* *} \pm 0.56$ & $6.43 \pm 0.45$ \\
All students could participate in discussions at full extend & $6.45^{*} \pm 0.35$ & $6.73^{* *} \pm 1.25$ \\
Materials of DER are useful for further professional work & $6.56 \pm 0.41$ & $6.45 \pm 0.38$ \\
\hline
\end{tabular}

Note: ${ }^{*}$ - differences at $\mathrm{p}<0.05 ;{ }^{* *}$ - differences at $\mathrm{p}<0.01$

display. Statistically reliable differences in students of various grades of higher professional education are revealed in indexes of "Purpose setting", "Planning" and "Correction".

Effectiveness of digital education resources usage is confirmed by growth of dynamics in all functional and personal components of self-organizing process in baccalaureate and undergraduate students. Selforganizing components of "Situation analysis" and "Purpose setting" have higher figures in undergraduate students. Statistically reliable shifts revealed in components of "Situation analysis" and "Planning" and also in general level of self-organizing. Besides this, statistical shifts were revealed in personal components of baccalaureates, and in self-organizing "Purpose setting" and "Self-control" components of undergraduates.

Survey results on self-evaluation of education process quality on "Flipped classroom" model given by baccalaureate and undergraduate students are shown in Table 3.

According to survey results it can be stated that in general students expressed highly positive response on structure and content of provided DER. All participants of study highly valued elaboration of course program, clearness and accuracy of the given teaching tasks and also educational value of content and usefulness of DER materials for future professional work (baccalaureates), convenience of forum organizing and possibility for all students to participate in discussions (undergraduates). 
High qualification of teacher, in opinion of students from various grades of higher professional education, appears in preparing of video-lectures, in supporting and helping students in conditions of digital and auditorium teaching.

Statistically reliable differences in baccalaureate and undergraduate students are revealed in such factors as convenience of forum organizing, evenness of teaching graphic, justifiability of academic load on students and possibility to participate in discussions at full extend.

Studies of many scientists prove that digital education technologies are the main trend in development of modern teaching system, in improvement of education quality and in corresponding of education process to actual demands of education service consumers.

Modern approach to usage of blended learning in teaching process stands on optimal choice of blended learning model with high potentiality for personalization and introducing pedagogical innovations.

Quality of blended education in great degree depends on how the teacher models interactive element in auditorium (Legan, 2017; Peres, Lima, \& Lima, 2016).

In carried out study there are presented different effective technological ways of "Flipped classroom" realization when creating digital education resources on various disciplines for baccalaureates and undergraduates.

As a result of applying this model of education technology there considerably changes situation in auditorium teaching in its focus and in roles of participants: teachers and students. So, students become active participants, and teachers switch on to function of tutor and facilitator. Effectiveness in choice of technological solution in realization of "Flipped classroom" model corresponds with opinions of foreign and native scientists (Baker, 2000; Downes, 2016; Vasilyeva, Rodionova, \& Chicherina, 2019).

Experimentally confirmed that when working in "Flipped classroom" model, on various technological foundations there are stimulated development of personal qualities and characteristics of students (motivation, activity, will effort), meta-subject skills (self-organizing), and also satisfaction by teaching arrangement and content of digital education resource. Obtained results correlate with data of native and foreign researchers in the field of flipped teaching (Kim et al., 2014; Pavelyeva, 2017; Sharples et al, 2014; Sun, Liu, \& Luo, 2017; Vorobyev \& Murzaeva, 2018; Yarbro et al., 2013; Zainuddin \& Halil, 2016).

Alongside, there are also revealed interesting facts, in particular, undergraduate students of distant education need more time and psychophysiological resources to make education graphic when studying and having job. Broadening dialogue interrelation of students with teacher and with classmates using social networks provides convenience in forum organizing and improves participation activity of students in discussions and in experience exchange.

\section{CONCLUSION}

Carried out pilot project on introduction of "Blended Learning" educational technology on the "Flipped classroom" model within realization scope of digital education resources at various levels of higher professional education, started on the base of Kazan (Volga region) federal university institute of psychology and pedagogics proved its trustworthiness.

Usage of digital education resource in undergraduate curriculum with technological realization of "Flipped classroom" model with high integration of interactive elements in digital and auditorium teaching provides every alternating stage of learning process by support of active dialogue interrelation of all participants in auditorium and online, and also with the help of social networks.

Teaching experience of baccalaureates showed that "Flipped classroom" model provides more flexibility in realization of educational process. Teacher is has more freedom in presentation of teaching materials. Also 
"Blended learning" provides multi-aspects in process of controlling and evaluating professional skills of students.

Effectiveness of digital education resources usage with "Flipped classroom" technology application in baccalaureate and undergraduate groups is confirmed by growth dynamics in all functional and personal components of self-organizing process; motivation increase in learning activity (educative-cognitive and professional motives, communicative motive that is professionally significant in the work of pedagogue and pedagogue-psychologist).

Baccalaureate and undergraduate students are satisfied by arrangement quality of digital teaching environment, content of DER (clearness and preciseness of purposes, course planning, justifiability of academic load on students, possibility to participate in discussions), and also qualification and responsiveness of teachers.

Obtained positive results of study lead to conclusion about possibility to replicate various options in "Flipped classroom" technology at different levels of higher professional education.

Further perspectives in development of digital education resources with usage of "Flipped classroom" model are in the following:

- broadening information environment through creating teacher's personal website for improvement of possibilities in dialogue interrelation arrangement;

- increasing amount of test tasks, practical tasks, elaboration of interactive tasks for students that are absent at practical lessons, broadening video content of the course;

- making and using of case studies for analyzing given information, finding key problem, searching and assessment of alternative solutions;

- making adaptive "Blended education" for possibility of individual educational trajectory of student.

\section{ACKNOWLEDGEMENTS}

The work is performed according to the Russian Government Program of Competitive Growth of Kazan Federal University.

\section{REFERENCES}

Badmaeva, N. Z. (2004). Motivation factor influence on development of intellectual abilities. Ulan-Ude: Publishing of VSGTU. Retrieved from https://search.rsl.ru/ru/record/01002834423

Baker, J. W. (2000). The Classroom Flip: Using Web Course Management Tools to Become the Guide on the Side. Selected Papers from the 11th International Conference on College Teaching and Learning, 9-17. Retrieved from http://www.classroomflip.com/files/classroom_flip_baker_2000.pdf

Bergmann, J., \& Sams, A. (2012). Flip Your Classroom: Reach Every Student in Every Class Every Day. Washington: International Society for Technology in Education.

Bluic, A. M., Casey, G., Bachfischer, A, Goodyear, P., \& Ellis, R. A. (2012). Blended learning in vocational education: teachers' conceptions of blended learning and their approaches to teaching and design. The Australian Educational Researcher, 2(39), 237-257. https://doi.org/10.1007/s13384-012-0053-0

Butakova, M. M., Sokolova, O. N., Zaitseva, N. A., Larionova, A. A., Ignatova, M. N., Trufanova, S. N., \& Yakovlev, A. Y. (2020). Evolution and current development trends of the Russian federation's higher education system. Opción, 36(Special Edition 27), 1718-1733.

Crouch, C. H., \& Mazur, E. (2001). Peer Instruction: Ten Years of Experience and Results. American Journal of Physics, 69, 970-977. https://doi.org/10.1119/1.1374249 
Downes, S. (2016). Ppersonal and personalized Learning. EMMA Newsletter. Retrieved from https://us8.campaign.archive.com/u=17ce08681f559814caf1359d3\&id=fa1770e58d\&e=-6fb12

Firsova, I., Vasbieva, D., Prokopyev, A. I., Zykin, E. S., \& Matvienko, V. V. (2018). Development of consumers' behavior business model on energy market. International Journal of Energy Economics and Policy, 8(4), 227-233.

Ishkov, A. D. (2004). Learning activity of student: psychological factors of success. Moscow: Publishing house ASB. https://doi.org/10.11621/pir.2015.0311

Kasprzak, A. G., \& Kalashnikov, S. P. (2014). Priority of educational results as the instrument in modernization of teacher training program. Psikhologicheskaya nauka i obrazovanie - Psychological science and education, 19(3), 87-104.

Kaygorodova, N. V., \& Shkurko, E. Y. (2016). Usage of "Flipped classroom" concept in higher education system. Omskij nauchny`j vestnik. Seriya "Obshhestvo. Istoriya. Sovremennost'» - Omsk scientific bulletin. Series "Society. History. Modern time", 1, 61-64.

Kim, M. K., Kim, S. M., Khera, O., \& Getman, J. (2014). The experience of three flipped classrooms in an urban university: An exploration of design principles. The Internet and Higher Education, 22, 37-50. https://doi.org/10.1016/j.iheduc.2014.04.003

Kondratenko, B. A. (2015). Personalization of professional education with usage of information and communication technologies (PhD thesis abstract). Kaliningrad. https://doi.org/10.21686/2500-39252015-5-8-13

Lage, M. J., Platt, G. J., \& Treglia, M. (2010). Inverting the Classroom: A Gateway to Creating an Inclusive Learning Environment. The Journal of Economic Education, 31, 30-43. Retrieved from https://www.tandfonline.com/doi/abs/10.1080/00220480009596759

Larionova, A. A., Zaitseva, N. A., Anoshina, Y. F., Gaidarenko, L. V., \& Ostroukhov, V. M. (2018). The modern paradigm of transforming the vocational education system. Astra Salvensis, 6, 436-448.

Legan, M. V. (2017). Arrangement and quality evaluation in blended learning of undergraduates on "Flipped classroom" model. Kachestvo. Innovaczii. Obrazovanie- Quality. Innovations. Education, 3(142), 9-17.

Luchenkova, E. B., Noskov, M. V., \& Shershneva, V. A. (2015). Blended learning in mathematics: practice defined theory. Vestnik KGPU im. V.P. Astaf'eva-Bulletin KSPU of V.P. Astafyev, 1(31), 54-59. Retrieved from http://www.kspu.ru/upload/documents/2016/12/20/0b35e1e6c0d-7681d85e16bc9153d9198/ nauchnyij-zhurnal-vestnik-kgpu-im-vp-astafeva-2016--4-38.pdf

Margolis, A. A. (2014) Problems and perspectives of pedagogical education in RF. Psikhologicheskaya nauka i obrazovanie - Psychological education and science, 19(3), 41-57.

Mohova, M. N. (2005). Active methods in blended learning in system of additional pedagogical education (Ph.D. Thesis). Moscow.

Pavelyeva, T. Y. (2017). Realization of "Flipped class" technology on "YourStudy" platform base. Vestnik Tambovskogo universiteta. Seriya Gumanitarny'e nauki - Bulletin of Tambov university. Series of Humanitarian sciences, 22(5), 82-87. https://doi.org/10.20310/1810-0201-2017-22-5(169)-82-87

Peres, P., Lima, L., \& Lima, V. (2016). B-learning Quality: Dimensions, Criteria and Pedagogical Approach. European Journal of Open Distance and E-Learning, 1(17), 56-75. DOI: https://doi.org/10.2478/eurodl2014-0004

Razumovskaya, M. I., Larionova, A. A., Zaitseva, N. A., Petrina, O. A, Vinogradova, M. V., Nagay, N. G., \& Takhumova, O. V. (2019). Models of Integrated Interactions Organization in the Field of Environmental Education. Journal of Environmental Treatment Techniques, 7(Issue 4), 576-580. 
Razumovskaya, M., Zaitseva N. A., Larionova, A. A., Chudnovskiy, A. D., \& Breusova, E. A. (2018). Prospects for applying various forms of organizational integration to improve the quality of education. Astra Salvensis, 6, 348-362.

Report NMC Horizon. (2015). Higher education - 2015. Retrieved from http://www.enu.kz/downloads/nauka/otchetNMC.pdf

Roschelle, J., Kaput, J., Stroup, W., \& Kahn, T. M. (1998). Scaleable integration of educational software: Exploring the promise of component architectures. Journal of Interactive Media in Education, 98(6), 175-187. https://doi.org/10.5334/1998-6

Ryu, H., \& Parsons, D. (2009). Designing learning activities with mobile technologies. Hershey: IGI Global. https://doi.org/10.4018/978-1-60566-062-2.ch001

Sharples, M., Adams, A., Ferguson, R., Gaved, M., McAndrew, P., Rienties, B., Weller, M., \& Whitelock, D. (2014). Innovating Pedagogy 2014: Open University Innovation Report 3. Milton Keynes: The Open University. Retrieved from http://www.openuniversity.edu/sites/www.open-university.edu/files/The _Open_University_Innovating_Pedagogy_2014_0.pdf

Spikol, D., Kurti, A., \& Milrad, M. (2008). Collaboration in context as a framework for designing innovative mobile learning. In H. Ryu \& D. Parsons (Eds.), Innovative mobile learning: Techniques and technologies (pp. 170-194). Hershey: Information Science Reference. https://doi.org/10.4018/978-1-60566-0622.ch009

Sun, Z., Liu, R., \& Luo, L. (2017). Exploring Collaborative Learning effect in Blending Learning Environments. Journal of Computer Assisted Learning, 6(33), 575-587. https://doi.org/10.1111/jcal.12201

Vasilyeva, Y. S., Rodionova E. V., \& Chicherina, N. V. (2019). Blended learning: models and real practice. Otkry toe i distanczionnoe obrazovanie - Open and distant education, 1(73), 22-32.

Vorobyev, A. E., \& Murzaeva, A. K. (2018). Analysis of particularities in usage of "Flipped classroom" technology at economic institutions. Otkry`toe obrazovanie - Open education, 2(22), 4-13. https://doi.org/10.21686/1818-4243-2018-2-4-13

Yarbro, J., McKnight, P., McKnight, K., \& Arfstrom, K. (2013). Extension of a review of Flipped Learning. George Mason University. Available at: https://flippedlearning.org/wp-content/uploads/2016/07/Extensionof-FLipped-Learning-LIt-Review-June-2014.pdf

Zainuddin, Z., \& Halili, S.H. (2016). Flipped Classroom Research and Trends from Different Fields of Study. The International Review of Research in Open and Distributed Learning, 17(3), 28-35. https://doi.org/10.19173/irrodl.v17i3.2274

Zyubina, I. A., Dzyubenko, A. I., Borisenko, V. A., Popova, O. V., \& Prokopyev, A. I. (2019). Implicit linguopragmatic strategies of speech behavior of English-speaking prosecutors. XLinguae, 12(4), 92102. https://doi.org/10.18355/XL.2019.12.04.08

Correspondence: Albina R. Drozdikova-Zaripova, PhD in Education, Associate Professor of the Institute of Psychology and Education, Kazan (Volga region) Federal University, Kazan, Russia. E-mail: bina1976@rambler.ru 